\title{
Clinical and epidemiological aspects of scorpion stings in the northeast region of Brazil
}

\author{
Aspectos clínicos e epidemiológicos dos acidentes escorpiônicos \\ na região do nordeste do Brasil
}

Rafaella Moreno Barros ${ }^{1}$

Jackeline Araujo Pasquino ${ }^{1}$

Laisla Rangel Peixoto ${ }^{1}$

Isabely Tamarys Gomes Targino ${ }^{1}$

Jorge Alves de Sousa ${ }^{1}$

Renner de Souza Leite ${ }^{1}$

${ }^{1}$ Unidade Acadêmica de Saúde, Centro de Educação e Saúde, Universidade Federal de Campina Grande. Olho

D’água da Bica s/n, Centro. 58.175-000 Cuité PB

Brasil.

rennerleite@yahoo.com.br
Abstract Scorpion stings are a serious public health issue in tropical and subtropical countries. This is a descriptive and retrospective study of the clinical-epidemiological characteristics of scorpion sting cases registered in the Health System in the city of Campina Grande, Paraíba state, from 2007 to 2012. Data was collected from the Injury Notification Information System data banks of the Ministry of Health. A total of 2,283 records, provided by the Third Health Sector of Campina Grande, were analyzed. Data revealed that the majority of the victims are female aged between 20 and 29 years, and the highest incidence of stings was in the urban area. Victims were mostly stung on the feet and hand. Serotherapy was not administered in most cases. The majority of the victims received medical assistance within 1 to 3 hours after the sting. The most prevalent clinical manifestations were pain, edema and paresthesias. Most cases were classified as mild, though seven deaths were reported. The high incidence rate suggests that this town may be an endemic area of scorpion stings, supporting the need to develop strategies to control and prevent scorpion stings.

Key words Paraíba State, Scorpion stings, Human poisoning, Scorpions, Epidemiology, Public health
Resumo Os acidentes escorpiônicos constituem um grave problema de saúde pública em países tropicais e subtropicais. Este estudo retrospectivo analisou as notificações dos acidentes escorpiônicos registrados no Sistema de Saúde do município de Campina Grande, no estado da Paraíba, de 2007 a 2012. As informações foram coletadas do banco de dados do Sistema de Informação de Agravos de Notificação do Ministério da Saúde. Foram analisadas 2283 fichas de notificação. Os dados revelaram que a maioria dos acidentados é do sexo feminino, com idade entre 20 e 29 anos. Os acidentes foram mais frequentes em área urbana, sendo os pés e as mãos os locais anatômicos do corpo mais atingidos pelas picadas. A soroterapia não foi administrada na maioria dos acidentados $e$ as vitimas prevalentemente recorreram aos sistemas de saúde dentro do período de 1 a 3 horas após o acidente. As manifestações clínicas mais frequentes foram dor, edema e parestesias. A maioria dos acidentes foi classificada como leve, porém foram registrados 7 casos de óbito. A elevada taxa de incidência de acidentes escorpiônicos sugere que esse município pode ser uma área endêmica de escorpiões, justificando a necessidade da elaboração de estratégias de controle e prevenção de acidentes por estes animais.

Palavras-chave Paraíba, Picada de escorpiões, Envenenamento humano, Escorpiões, Epidemiologia, Saúde Pública 


\section{Introduction}

Scorpion envenomations have been considered a public health problem in tropical and subtropical countries due to their high incidence and potentiality of venom of some species to induce severe clinical registers, sometimes fatal ones ${ }^{1}$. In Brazil, three species of scorpions of Tityus type have been responsible for stings of medical importance: T. stigmurus T. bahiensis and T. serrulatus, the last one being the main species responsible for severe stings, with death register mainly in children ${ }^{2}$. Epidemiological studies on scorpion stings have revealed that their incidence is most frequent in male individuals, aged between 20 and 40 years, and that they are predominantly stung on the feet and legs ${ }^{3}$. Most of the cases take place in urban area, inside or nearby home, with seasonal distribution in the South and Southeast states during the warm and rainy months, being however practically invariable all year long in the north, northeast and center-west ${ }^{3}$. The seriousness of the case depends on factors such as the species and size of the scorpion, the amount of venom inoculated, the victim's body mass and the patient's sensitivity to poison. Early diagnosis, time elapsed between the sting and serotherapy, and the maintenance of the victim's vital functions also interfere in the case evolution ${ }^{2}$.

In Brazil, the registering system of scorpion stings was established in 1988 and, since then, the number of cases has increased significantly. In 2011 , it was estimated that about 58,000 scorpion sting cases, with incidence of 52 cases $/ 100,000$ inhabitants ${ }^{4}$. In spite of the significant increase of data originated from states of northeast such as Bahia, Rio Grande do Norte, Pernambuco, Alagoas and Ceará, the highest number of registers is from the state of Minas Gerais ${ }^{5}$. In the northeast, the epidemiological profile of scorpion sting cases is not yet clarified, and the Tityus stigmurus has been pointed out as the main offending species $^{6,7}$. Despite the medical importance regarding scorpion stings and the increasing number of registers in the northeast, the epidemiology of these stings in the state of Paraíba is still poorly understood. In this sense, this research aims to evaluate clinical-epidemiological data of scorpion sting cases in the period from 2007 to 2012, in the town of Campina Grande, Paraíba.

\section{Materials and Methods}

\section{Study area}

The study was accomplished in the city of Campina Grande, located in the countryside of Paraiba state, in the northeast of Brazil. The mentioned town is placed in the Paraíba agreste, eastern part of the Planalto da Borborema, at an average altitude of 555 meters above sea level and it has tropical climate of altitude, with average annual temperature of $25^{\circ} \mathrm{C}$. Its population was estimated around 385,276 inhabitants, covering a geographical area of $599.6 \mathrm{Km}^{2}$, with demographic density of 597.9 inhabitants/ $/ \mathrm{Km}^{28}$.

\section{Data Acquisition}

A descriptive and retrospective study of the clinical-epidemiological characteristics of scorpion sting cases was performed. The epidemiological data was obtained from information present in the registers of scorpion sting cases which occurred in the city of Campina Grande, in the period from 2007 to 2012. Data collection was carried out in the Third Health Sector of Campina Grande, using the SINAN (Injury Notification Information System) databases of the Health Ministry. Epidemiological data was analyzed according to sex, age, year and month of the scorpion sting, zone of occurrence (urban or rural), part of the body stung, and time elapsed between sting and medical assistance. The variables investigated in clinical evaluations were: local and systemic clinical manifestations, seriousness and evolution of the case, and serotherapy. Demographic and population data furnished by the Brazilian Institute of Geography and Statistics (IBGE) were used to calculate incidence rates. Statistical analyses were performed using the Analysis of Variance (one-way ANOVA) and Tukey tests. The level of significance was set at $\mathrm{p}<0.05$. All statistical analyses were performed using the software R version 2.15.1 for Windows.

\section{Results}

Between January/2007 and December/2012, a total of 2,283 scorpion stings were notified and given care in the town of Campina Grande, with average incidence rate of 132 cases/100,000 inhabitants in 2007, 127 cases/100,000 inhabitants in 2008, 109 cases/ 100,000 inhabitants in 2009, 47 cases/100,000 inhabitants in 2010, 68 cases/ 
100,000 inhabitants in 2011, 108 cases/ 100,000 inhabitants in 2012. Table 1 shows the month distribution of scorpion sting cases. Such scorpion stings occurred during the whole studied period, with irregular monthly distribution of the cases. No statistical difference was observed when comparing months $(\mathrm{p}=0.6620)$. Table 2 shows the individual characterization and circumstances of the reported scorpion stings. Victims were predominantly female $(\mathrm{n}=1,371 ; 60.05 \%)$ and were not at work at the time of the sting $(\mathrm{n}=$ $2,095 ; 39.94 \%)$. Most cases occurred in urban area $(n=2,062 ; 90.3 \%)$. In terms of age range, the highest frequency of stings was found in individuals between 20 and 29 years old ( $\mathrm{n}=493$; $21.59 \%$ ), followed by age range between 10 and 19 years old $(\mathrm{n}=395 ; 17.30 \%)$, no statistical difference was observed between the age ranges ( $p$ $=0.7775)$. The lowest frequency was observed in individuals above 70 years old $(\mathrm{n}=110 ; 4.81 \%)$, for both genders. The part of the body mostly stung was the feet $(\mathrm{n}=743 ; 32.54 \%)$ when compared with the others anatomic regions $(\mathrm{p}<0.05)$. The most frequent time interval, elapsed between the sting and medical assistance, was of 0 to 1 hours after the sting $(\mathrm{n}=627 ; 27.46 \%)$, followed by time interval of 1 to 3 hour $(n=545 ; 23.87 \%)$. No statistical difference between these time intervals $(\mathrm{p}=0.05)$. Serotherapy was fulfilled in only 19 patients $(0.83 \%)$, and in 2,226 patients (97.50\%) antivenom was not administered. Table 3 shows the clinical classification and the evo- lution of the cases. The majority of the cases $(\mathrm{n}=$ 2,$209 ; 96.75 \%$ ) was classified as mild; just a few cases as moderate $(\mathrm{n}=52 ; 2.27 \%)$ and four as severe $(\mathrm{n}=4 ; 0.17 \%)$. Evolution for cure was predominant $(n=2,211 ; 96.84 \%)$. A total of seven deaths $(0.30 \%)$ were registered. Table 4 shows local and systemic clinical manifestations observed as a result of scorpion stings. The most frequent local manifestations were pain $(\mathrm{n}=$ $2,195 ; 96.14 \%)$, edema $(n=693 ; 30.35 \%)$, paresthesia $(n=455 ; 19.92 \%)$ and ecchymosis $(n=33$; $1.44 \%)$. The most frequent systemic clinical manifestations were generalized pains $(\mathrm{n}=38 ; 1.66 \%)$, vagal manifestations $(\mathrm{n}=24 ; 1.05 \%)$ and arterial hypotension $(n=6 ; 0.26 \%)$.

\section{Discussion}

In the city of Campina Grande, between 2007 and 2012, a number of 2,283 scorpion stings were registered. Such cases presented average annual incidence of 98 cases/100,000 inhabitants. Table 1 show the case distribution in relation to the months. The scorpion stings occurred mostly from July to September. However, no statistical difference was observed between the months ( $p$ $=0.6620)$. The distribution of cases during the year with little variation between the months may be attributed to region climatic conditions, characterized by defined climatic seasons and average annual temperature of $25^{\circ} \mathrm{C}$. These conditions

Table 1. Distribution by month of scorpion sting cases registered in the municipality of Campina Grande, State of Paraíba, Brazil, from 2007 to 2012 ( $\mathrm{n}=2283)$.

\begin{tabular}{|c|c|c|c|c|c|c|c|}
\hline \multirow[b]{2}{*}{ Variables } & \multicolumn{6}{|c|}{ Year } & \multirow[b]{2}{*}{ Total } \\
\hline & 2007 & 2008 & 2009 & 2010 & 2011 & 2012 & \\
\hline \multicolumn{8}{|l|}{ Months } \\
\hline January & 41 & 41 & 58 & 48 & 17 & 34 & 239 \\
\hline February & 52 & 35 & 62 & 14 & 48 & 38 & 249 \\
\hline March & 44 & 46 & 39 & 23 & 9 & 43 & 204 \\
\hline April & 25 & 26 & 0 & 5 & 0 & 35 & 91 \\
\hline May & 50 & 49 & 51 & 13 & 1 & 41 & 205 \\
\hline June & 34 & 26 & 37 & 0 & 0 & 0 & 97 \\
\hline July & 62 & 60 & 25 & 11 & 46 & 61 & 265 \\
\hline August & 56 & 60 & 30 & 3 & 39 & 71 & 259 \\
\hline September & 44 & 57 & 31 & 12 & 46 & 49 & 239 \\
\hline October & 38 & 37 & 18 & 0 & 27 & 0 & 120 \\
\hline November & 25 & 31 & 32 & 4 & 29 & 0 & 121 \\
\hline December & 39 & 21 & 40 & 49 & 0 & 45 & 194 \\
\hline Total & 510 & 489 & 423 & 182 & 262 & 417 & 2.283 \\
\hline
\end{tabular}

No statistical significant difference was observed between the months. 
Table 2. Descriptive analyses of scorpion sting cases registered in the municipality of Campina Grande, State of Paraíba, Brazil, from 2007 to 2012, according to quantitative demographic variables $(\mathrm{n}=2283)$.

\begin{tabular}{|c|c|c|c|c|c|c|c|}
\hline \multirow{2}{*}{ Variables } & \multicolumn{6}{|c|}{ Year } & \multirow[b]{2}{*}{ Total } \\
\hline & 2007 & 2008 & 2009 & 2010 & 2011 & 2012 & \\
\hline \multicolumn{8}{|l|}{ Age group (years) } \\
\hline $1|-| 9$ & 43 & 50 & 46 & 23 & 29 & 65 & $256^{*}$ \\
\hline $10|-| 19$ & 85 & 92 & 72 & 36 & 40 & 70 & $395^{*}$ \\
\hline $20|-| 29$ & 131 & 92 & 102 & 39 & 49 & 80 & 493 \\
\hline $30|-| 39$ & 77 & 81 & 68 & 24 & 44 & 65 & 359 \\
\hline $40|-| 49$ & 59 & 72 & 46 & 31 & 37 & 55 & 300 \\
\hline $50 \mid-59$ & 66 & 49 & 55 & 13 & 19 & 38 & 240 \\
\hline $60|-| 69$ & 28 & 28 & 14 & 9 & 23 & 28 & 130 \\
\hline$\geq 70$ & 21 & 25 & 20 & 7 & 21 & 16 & 110 \\
\hline Unknown & 0 & 0 & 0 & 0 & 0 & 0 & 0 \\
\hline Total per age group & 510 & 489 & 423 & 182 & 262 & 417 & 2.283 \\
\hline \multicolumn{8}{|l|}{ Gender } \\
\hline Male & 184 & 202 & 174 & 72 & 114 & 166 & 912 \\
\hline Female & 326 & 287 & 249 & 110 & 148 & 251 & $1.371^{*}$ \\
\hline Total & 510 & 489 & 423 & 182 & 262 & 417 & 2283 \\
\hline \multicolumn{8}{|l|}{ Localities of Occurrence } \\
\hline Urban & 465 & 431 & 388 & 164 & 241 & 373 & $2.062^{*}$ \\
\hline Rural & 34 & 44 & 26 & 10 & 17 & 39 & 170 \\
\hline Periurban & 1 & 1 & 0 & 1 & 0 & 0 & 3 \\
\hline Unknown & 10 & 13 & 9 & 7 & 4 & 5 & 48 \\
\hline Total & 510 & 489 & 423 & 182 & 262 & 417 & 2.283 \\
\hline \multicolumn{8}{|l|}{ Work-related accident } \\
\hline Yes & 9 & 11 & 17 & 10 & 17 & 18 & 82 \\
\hline No & 455 & 435 & 398 & 170 & 240 & 397 & $2.095^{*}$ \\
\hline Unknown & 46 & 43 & 8 & 3 & 5 & 2 & 106 \\
\hline Total & 510 & 489 & 423 & 183 & 262 & 417 & 2.283 \\
\hline \multicolumn{8}{|l|}{ Part of the body stung } \\
\hline Forearm & 3 & 2 & 7 & 2 & 2 & 11 & 27 \\
\hline Hand & 85 & 72 & 58 & 15 & 24 & 45 & 299 \\
\hline Leg & 16 & 13 & 16 & 6 & 10 & 13 & 74 \\
\hline Foot & 173 & 157 & 125 & 61 & 85 & 133 & $734^{*}$ \\
\hline Arm & 10 & 11 & 15 & 6 & 8 & 10 & 60 \\
\hline Unknown & 178 & 175 & 54 & 1 & 3 & 1 & 412 \\
\hline Total & 465 & 430 & 275 & 91 & 132 & 213 & 1.606 \\
\hline \multicolumn{8}{|l|}{ Antivenom } \\
\hline Yes & 3 & 1 & 6 & 3 & 1 & 5 & 19 \\
\hline No & 502 & 471 & 410 & 176 & 255 & 412 & 2.226 \\
\hline Unknown & 5 & 17 & 7 & 3 & 6 & 0 & 38 \\
\hline Total & 510 & 489 & 423 & 182 & 262 & 417 & 2.283 \\
\hline \multicolumn{8}{|c|}{ Time from sting until assistance (hours) } \\
\hline $0|-| 1$ & 53 & 39 & 149 & 87 & 121 & 178 & $627^{*}$ \\
\hline $1|-| 3$ & 89 & 137 & 84 & 44 & 62 & 129 & $545^{*}$ \\
\hline $3|-| 6$ & 8 & 13 & 20 & 11 & 29 & 45 & 126 \\
\hline $6|-| 12$ & 7 & 0 & 16 & 7 & 15 & 22 & 67 \\
\hline$\geq 12$ & 11 & 6 & 23 & 13 & 10 & 19 & 82 \\
\hline$\overline{\text { Unknown }}$ & 342 & 294 & 131 & 20 & 25 & 24 & 836 \\
\hline Total & 510 & 489 & 423 & 182 & 262 & 417 & 2.283 \\
\hline
\end{tabular}

" $\mathrm{p}<0.05$ significant when compared to the other variables (Tukey Test). 
Table 4. Clinical manifestations of scorpion sting victims registered in the municipality of Campina Grande, State of Paraíba, Brazil, from 2007 to 2012 $(\mathrm{n}=2283)$.

\begin{tabular}{lrlr}
\hline \multicolumn{4}{c}{ Clinical Manifestations } \\
\hline \multicolumn{1}{c}{ Local } & \multicolumn{1}{c}{ N } & \multicolumn{1}{c}{ Systemic } & N \\
\hline Pain & 2.195 & Pains & 38 \\
Edema & 693 & Vagal Manifestations & 24 \\
Paresthesia & 455 & Arterial Hypotension & 6 \\
Ecchymosis & 33 & Myolytic & 6 \\
Headache & 5 & Manifestations & \\
Necrosis & 4 & Neurological & 5 \\
Itching & 2 & Manifestations & \\
Erythema & 0 & Chills & 1 \\
Local Bleeding & 0 & & \\
Abscess & 0 & & \\
Local Dormancy & 0 & & \\
Teeth Marks & 0 & & \\
Dizziness & 0 & & \\
\hline
\end{tabular}

can favor the reproductive activities of scorpions, with consequent maintenance of stings throughout the year. On the other hand, in the south and southeast regions of Brazil, the stings follow a noteworthy seasonality, being more frequent from October to December, ${ }^{9,10}$. Santos et al. ${ }^{11}$, investigating the epidemiology of scorpion stings in the state of Minas Gerais, it observed a higher frequency of cases in the urban area. In present study, the most of scorpion sting cases occurred in urban area $(\mathrm{n}=2,062 ; 90.31 \%)(\mathrm{Ta}-$ ble 2). Scorpions became adapted to urban home life, possibly due to the presence of man in regions originally occupied by these animals. Therefore, they had to adapt themselves to the conditions offered by human housing, getting shelter in places containing garbage, piles of bricks and roof tiles, and being generally fed with insects ${ }^{12}$. Furthermore, the lack of predators and natural competitors, such as monkeys, chickens, toads and frogs can contribute to the fast proliferation of scorpions, since this is an important factor for the population control of these animals ${ }^{13}$. According to Albuquerque et al. ${ }^{14}$ the increase of the scorpion stings in urban areas of Campina Grande is resultant of ideal conditions for shelter and proliferation of these animals, such as the presence of debris, garbage and plenty of food, besides the high demographic density and the lack of basic sanitation. These observations were also reported by the studies by Sales et al. ${ }^{15}$.

Results of the current study show that scorpion stings were more frequent in female individuals $(\mathrm{n}=1,371 ; 60.05 \%)$. Albuquerque et al. ${ }^{14}$, in a study carried out in Campina Grande, reported that the risk of scorpion sting among women is higher than that among men. This is due to the fact that women do housework involving cleaning activities in locals frequently housed by scorpions. On the other hand, these results differ from data registered for other municipalities in the north and northeast regions of Brazil, where there is predominance of attacks in male individuals ${ }^{5,16}$. Such difference in results may be due to a higher exposure of the female gender to situations favorable to stings; this is probably related to occupational and behavioral differences in home environment ${ }^{13}$. In this study, there was a higher incidence of scorpion stings in individuals aged between 20 and 29 years ( $\mathrm{n}=493 ; 21.59 \%)$, followed by those aged between 10 and 19 years $(\mathrm{n}=395 ; 17.30 \%)$, thus indicating that the highest number of stings occurs in the economically active population. This is in accordance with the studies carried out by Albuquerque et al. ${ }^{14}$, in Campina Grande and by other authors for different regions ${ }^{17}$. However, no significant difference between the cases of scorpion sting when compared to age. This result suggests that individuals of all ages are vulnerable to scorpion stings. This reinforces the need for the development of preventative education campaigns for this type of accident. 
The high incidence of data ignored and not filled up referring to the part of the body stung ( $\mathrm{n}=412 ; 18.04 \%)$ is pointed out. Even though, the lower limbs was the main part of the body stung, especially the feet $(n=734 ; 32.15 \%)$. On the other hand, most of the epidemiological studies show that the upper limbs, especially the hands, are the part of the body frequently attacked by the stings $s^{5,711}$. In the current study, most victims received medical assistance up to 3 hours following the sting ( $\mathrm{n}=1172 ; 51.33 \%)$, similar to what was observed in some municipalities of the state of São Paulo ${ }^{17}$ and Uberlândia, in the state of Minas Gerais ${ }^{18}$, where the majority of the victims received care in the first two or three hours after the sting. However, it is important to highlight that out of the 2,283 victims who sought medical care, 275 (12.04\%) did it only after 3 hours following sting, and in 836 cases $(36.61 \%)$ the time elapsed between sting and medical assistance was ignored or not registered. The majority of cases were classified as mild ( $\mathrm{n}=$ $2,209 ; 96.75 \%)$. The case classification was similar to data reported for Campina Grande ${ }^{14}$, as well as for other regions of the country ${ }^{7,16}$. Most cases evolved for healing ( $\mathrm{n}=2,211 ; 96.84 \%)$ and seven for death $(0.30 \%)$. The cause of the deaths was not registered. The cases that resulted in death were classified as mild and antivenom was not administered. It is possible that deaths may have occurred due to failure in classifying the severity of the cases. Serotherapy was accomplished in 19 cases $(0.83 \%)$, however, the type of antivenom was not registered. Local pain was notified in almost $100 \%$ of the cases and the registered clinical manifestations, either local or systemic, were similar to those described in other studies carried out both in Paraíba and other states ${ }^{7,14,16}$. The low number of severe cases may be the most probable cause of the reduced number of deaths observed in this study.

Various deficiencies were identified on the notification files, such as the lack of accounts of the time of day when the sting occurred and the genus of the offending scorpion, and the high proportions when the clinical evolution of the patient and the time elapsed between sting and medical care was not reported. These deficiencies on the clinic charts may be related to the unusual high demands at the health centers, the lack of available time of members of the health team, or little number of workers at the health center ${ }^{18}$. These situations should be emphasized once they are all common in health care centers in the northeastern Brazil, and will all contribute to the incomplete patient records. The improvement of data collection, fulfilled by local health agencies, is of remarkable importance in order to make up reliable information sources. Register files evaluated in this study were not suitably filled up, thus indicating deprivation of health services. Flaw in register services makes the scorpion envenomation difficult to be fully understood in certain regions of the country. To aggravate this situation, the curricula of university courses in medicine, pharmacy and nursing are almost always deficient in terms of instruction about attacks by poisonous animals ${ }^{19}$. Finally, the results of the current study may contribute to improve understanding of the epidemiology of scorpion stings in the state of Paraíba. Such knowledge may in turn provide relevant information for enhancing policies of antivenom production and distribution in the northeast region, as well as boost care given to scorpion envenomation victims. Furthermore, this research may supply important data for the development of educational campaigns aiming at preventive control of scorpion stings. 


\section{Collaborations}

JA Pasquino, LR Peixoto, ITG Targino, and RM Barros worked in the survey of the literature, in the research and methodology. JA Sousa worked on statistical analysis of data and RS Leite worked on the conception and design the study, analysis and interpretation data, wrote the first version of the article.

\section{Acknowledgements}

The authors are grateful to the workers of the $2^{\circ}$ and $3^{\circ}$ Gerência de Saúde of the state of Paraíba for gently providing us with the epidemiological data.

\section{References}

1. Chippaux JP, Stock RP, Massougbodji A. Methodology of clinical studies dealing with the treatment of envenomation. Toxicon 2010; 55(7):1195-1212.

2. Albuquerque CMR, Porto TJ, Amorim MLP, Santana-Neto PL. Escorpionismo por Tityus pusillus Pocock, 1893 (Scorpiones; Buthidae) no Estado de Pernambuco. Revista da Sociedade Brasileira de Medicina Tropical 2009; 42(2):206-208.

3. Brasil. Ministério da Saúde (MS). Manual de Controle de Escorpiões. Brasília: MS; 2009.

4. Brasil. Ministério da Saúde (MS). Secretaria de Vigilância em Saúde. Sistema de Informação de Agravos de Notificação (SINAN). [Internet]. [cited 2013 Mar 5]. Casos de acidentes por escorpiões. Brasil, Grandes Regiões e Unidades Federadas. 2000 a 2011. Available from: http://portalsaude.saude.gov.br/portalsaude/texto/5817/783/acidentes-por-escorpiões.

5. Lira-da-Silva RM, Amorim AM, Brazil TK. Envenenamento por Tityus stigmurus (Scorpiones; Buthidae) no Estado da Bahia, Brasil. Rev Sociedade Brasileira de Medicina Tropical 2000; 33(3):239-245.

6. Barbosa MGR, Bavia ME, Silva CEP, Barbosa FR. Aspectos epidemiológicos dos acidentes escorpiônicos em Salvador, Bahia, Brasil. Ciência Animal Brasileira 2003; 4(2):155-162.

7. Lira-da-Silva RM, Amorim AM, Carvalho FM, Brazil TK. Acidentes por escorpião na cidade de Salvador, Bahia, Brasil (1982-2000). Gazeta Médica da Bahia 2009; 79:43-49.

8. Instituto Brasileiro de Geografia a Estatística (IBGE). Censo Demográfico 2010. [site] [Internet]. [cited 2010 nov 22]. Available from: http://www.ibge.gov.br/ home/estatistica/populacao/censo2010/default.shtm

9. Silva FG, Tavares-Neto J. Avaliação dos Prontuários Médicos de Hospitais de Ensino do Brasil. Revista Brasileira de Educação Médica 2007; 31(2):113-126.

10. Taveira LA, Ferreira CS, Carvalho ME, Eickstedt VTD, Rodrigues F, Fabbro ALD Escorpionismo no município de Sertãozinho, S.P. Memórias do Instituto Butantan 1990; 52(Supl. 37): 80-84.

11. Santos PLC, Martins FJ, Vieira RCPA, Ribeiro LC, Barreto BB, Barbosa NR. Características dos acidentes escorpiônicos em Juiz de Fora - MG. Rev Atenção Primária a Saúde 2010; 13(2):164-169.

12. Nodari FR, Leite ML, Nascimento E. Aspectos demográficos, espaciais e temporais dos acidentes escorpiônicos ocorridos na área de abrangência da $3^{\circ}$ Regional de Saúde - Ponta Grossa, PR, no período de 2001 a 2004. Rev Ciência Biologia Saúde 2006; 12(1):15-26.

13. Soares MRM, Azevedo CS, De Maria M. Escorpionismo em Belo Horizonte, MG: um estudo retrospectivo. Rev Sociedade Brasileira de Medicina Tropical 2002; 35(4):359-363.

14. Albuquerque ICS, Albuquerque HN, Albuquerque EF, Nogueira AS, Cavalcante LMF. Escorpionismo em Campina Grande (PB). Rev. Biologia e Ciências da Terra 2004; 4(1):2-10.

15. Sales IC, Albuquerque HN, Castro LA, Batista AR, Braga SMLFM. Acidentes escorpiônicos notificados em Campina Grande (PB). Rev. Brasileira de Toxicologia 1999; 12(2):87-88. 
16. Pardal PPO, Castro LC, Jennings E, Pardal JSO, Monteiro MRCC. Aspectos epidemiológicos e clínicos do escorpionismo na região de Santarém, Estado do Pará, Brasil. Rev. Sociedade Brasileira de Medicina Tropical 2003; 36(3):349-353.

17. Ribeiro AL, Rodrigues L, Jorge MT. Aspectos clínicos e epidemiológicos do envenenamento por escorpiões em São Paulo e municípios próximos. Rev. Patologia Tropical 2001; 30(1):83-92.

18. Silva FG, Queiroz FM, Ribeiro LB, Ribeiro LA, Borges PP, Motta RF, Spina VP, Assunção VF. Acidentes por escorpião: avaliação epidemiológica e clínica de 764 casos do HC-UFU de 1987 a 1996. Rev. Sociedade Brasileira de Medicina Tropical 1999; 32(Supl. 1): 385-390.

19. Oliveira HFA, Leite RS, Costa CF. Aspectos clínicoepidemiológicos de acidentes com serpentes peçonhentas no município de Cuité, Paraíba, Brasil. Gazeta Médica da Bahia 2011; 81(1):14-19.

Artigo apresentado em 20/03/2013

Aprovado em 28/04/2013

Versão final apresentada em 17/05/2013 